\title{
EFEKTIVITAS METODE PEMBELAJARAN AKTIF TIPE GROUP TO GROUP EXCHANGE (GGE) TERHADAP HASIL BELAJAR MATEMATIKA SISWA KELAS VIII SMP PESANTREN MODERN DATOK SULAIMAN (PMDS) PUTRI PALOPO
}

\author{
Oleh: ${ }^{1}$ Dewi Purwati, ${ }^{2}$ Muhammad Hajarul Aswad A \\ ${ }^{1,2}$ Pendidikan Matematika IAIN Palopo \\ e-mail: ${ }^{2}$ as_wad82@yahoo.co.id
}

\begin{abstract}
Abstrak:
Pembelajaran aktif tipe Group to Group (GGE) merupakan salah satu metode belajar dimana siswa yang terbagi kedalam kelompok diberikan tugas yang bebeda untuk kemudian dipersentasekan kepada kelompok lain.penelitin ini bertujuan untuk melihat efektifitas efektifitas metode pembelajaran aktif tipe Group to Group Exchange (GGE) terhadap hasil belajar matematika siswa kelas VIII SMP. Secara deskriptif, rata-rata hasil belajar matematika siswa kelas VIII SMP Pesantren Modern Datok Sulaiman (PMDS) Putri Palopo yang diajar dengan metode pembelajaran Group to Group Exchange (GGE) lebih tinggi apabila dibandingkan dengan kelas yang tidak diajarkan dengan metode pembelajaran tersebut. Hal ini berarti bahwa metode pembelajaran aktif tipe Group to Group Exchange (GGE) efektif dalam meningkatkan hasil belajar matematika siswa kelas VIII SMP
\end{abstract}

Kata kunci:: Group to Group Exchange, Hasil Belajar Matematika.

\section{Pendahuluan}

Matematika sebagai ilmu dasar, disajikan disetiap jenjang pendidikan. Di dalam proses pembelajarannya memerlukan keterampilan khusus yang dapat mengantarkan siswa untuk memfokuskan perhatiannya secara penuh pada pelajaran. Karena itu guru sebagai suatu profesi mempersyaratkan berbagai kemampuan dan keterampilan minimal penguasaan materi dan keterampilan mengajarkannya.

Meskipun matematika dipandang sulit, semua orang mesti mempelajarinya karena merupakan sarana untuk memecahkan masalah sehari-hari. Seperti halnya bahasa, membaca dan menulis, kesulitan belajar matematika harus diatasi sedini mungkin kalau tidak siswa akan menghadapi banyak masalah karena hampir semua bidang studi memerlukan matematika yang sesuai. 
Banyak anak berkesulitan belajar matematika yang penyebabnya adalah kurangnya kesiapan anak untuk mempelajari bidang studi tersebut. Diperlukan banyak waktu dan tenaga untuk membangun kesiapan belajar agar anak tidak mengalami banyak masalah dalam bidang studi matematika. Salah satu bentuk penyajian materi yang dianggap dapat memecahkan persoalan tersebut adalah dengan pemberian tugas kelompok.

Group To Group Exchange (GGE) merupakan salah satu metode pembelajaran aktif yang memanfaatkan kelompok belajar untuk memaksimalkan belajar. Kelompok dibuat heterogen untuk menghindari penguasaan pada proses pembeljaran oleh salah satu kelompok.masing-masing kelompok mendapatkan topik yang berbeda. Metode ini merupakan gabungan dari metode diskusi, tanya jawab dan mengajarkan teman sebaya. Atas alasan tersebut, maka peneliti tertarik untuk melihat efektifitas metode pembelajaran aktif tipe Group to Group Exchange (GGE) terhadap hasil belajar matematika siswa kelas VIII SMP Pesantren Modern Datok Sulaiman (PMDS) putri Palopo.

Prosedur pembelajaran tipe GGE adalah sebagai berikut :

1) Memilih suatu topik beragam gagasan, peristiwa, posisi, konsep atau pendekatan untuk ditugaskan pada siswa. Topik tersebut haruslah dapat membuat siswa bertukar pandangan atau informasi.

2) Membagi kelas itu kedalam kelompok sesuai dengan banyak tugas. Kemudian memberi masing-masing kelompok waktu yang cukup untuk mempersiapkan penyajian topik yang ditugaskan pada kelompok tersebut.

3) Ketika tahap persiapan telah diselesaikan, mintalah pada kelompok untuk memilih siapa sebagai juru bicaranya. Mintalah masing-masing juru bicara untuk mempresentasikan tugas tersebut secara jelas dan ringkas. Kemudian mintalah kepada kelompok lainnya untuk memberikan pertanyaan atau pandangan mereka sendiri terhadap presentasi kelompok penyaji. Apabila ada pertanyaan yang meragukan atau menyulitkan kelompok penyaji maka anggota kelompok lain diizinkan untuk menjawab.

4) Melanjutkan presentasi berikutnya dari kelompok yang berbeda. Sedemikian sehingga masing-masing kelompok dapat membandingkan informasi dan pandangan yang telah didapatkaannya. 
73 | al-Khwarizmi, Volume III, Edisi 2, Oktober 2015, Hal. 71 - 76

\section{Metode Penelitian}

Pendekatan yang digunakan dalam penelitian ini adalah pendekatan Pedagogik dan Psikologis. Jenis penelitian ini adalah penelitian True Experimen (Eksperimen Murni). Penelitian ini dilakukan di SMP Pesantren Modern Datok Sulaiman (PMDS) Putri Palopo tahun ajaran 2015/2016. Populasi dalam penelitian ini adalah siswa kelas VIII SMP Pesantren Modern Datok Sulaiman (PMDS) Putri Palopo tahun ajaran 2015/2016 yang terdiri dari 4 kelas yang berjumlah 103 siswa. Dari 4 kelas tersebut kemudian terpilih secara acak 2 kelas yakni kelas VIII.B yang diajar dengan GGE yang kemudian disebut dengan kelas eksperimen dan kelas VIII.C yang tidak diajar dengan GGE yang kemudian disebut dengan kelas kontrol. Jumlah siswa dari masing-masing kelas adalah sama yakni 22 siswa. Adapaun desain yang digunakan dalam penelitian ini adalah sebagai berikut:

\begin{tabular}{|c|c|c|c|}
\hline Kelompok & Pre Test & Variabel Bebas & Post Test \\
\hline Kelas Eskperimen & Y.1 & X & Y.2 \\
\hline Kelas Kontrol & Y.1 & - & Y.2 \\
\hline
\end{tabular}

Dengan :

$\mathrm{Y} .1=$ pre test untuk kelas eksperimen dan kelas kontrol

$\mathrm{X}=$ perlakuan

Y.2 = post test untuk kelas eksperimen dan kelas kontrol

Data yang digunakan dalam penelitian ini ada 2 yakni data primer yang terdiri dari hasil tes dan wawancara singkat dengan pihak sekolah, dan data sekunder berupa dokumentasi dan sebagainya terkait penelitian ini.

Sebelum diberikan kepada kelas sampel, instrumen tes terlebih dahulu divalidasi dengan menggunakan statistik Aiken's V. Selanjutnya, sebelum dilakuakn uji hipotesis, terlebih dulu dilakukan uji syarat homogenitas dengan menggunakan uji $F$ dan normalitas dengan menggunakan aturan chi-kuadrat.

Efektifitas penerapan metode Group to Group Exchange terhadap hasil belajar matematika siswa diketahui dengan membandingkan hasil post-tes kelas ekesperimen dan kelas ekserimen. GGE dikatakan efektif meningkatkan hasil belajar matematika siswa apabila rata-rata hasil belajar matematika siswa kelas eksperimen signifikan lebih tinggi daipada rata-rata hasil belajar matematika siswa kelas kontrol. Hipotesis statistiknya adalah sebagai berikut: 
dengan:

$$
\mathrm{H}_{0}: \mu_{1} \leq \mu_{2} \text { melawan } \mathrm{H}_{1}: \mu_{1}>\mu_{2}
$$

$\mu_{1}=$ Rata-rata data siswa sesudah perlakuan (kelas eksperimen)

$\mu_{2}=$ Rata-rata data siswa tanpa perlakuan (kelas kontrol)

Untuk menjawab hipotesis digunakan uji $\mathrm{z}$ dengan persamaan sebagai berikut:

Keterangan:

$$
D s g=\sqrt{\frac{\left(n_{1}-1\right) S_{1}^{2}+\left(n_{2}-1\right) S_{2}^{2}}{n_{1}+n_{2}-2}}
$$

$S_{1}^{2}=$ Varians data sampel kelas eksperimen

$S_{2}^{2}=$ Varians data sampel kelas control

Uji - z dipengaruhi oleh hasil uji varians antara kedua kelompok, dengan rumus $\mathrm{Z}$ yang digunakan adalah:

$$
Z=\frac{\bar{x}_{1}-\bar{x}_{2}}{\operatorname{dsg} \sqrt{\frac{1}{n_{1}}+\frac{1}{n_{2}}}}
$$

Keterangan:

$\mathrm{z}=$ Statistik uji

$\bar{x}_{1}=$ Mean sampel kelompok eksperimen

$\bar{x}_{2}=$ Mean sampel kelompok kontrol

$d s g=$ Nilai deviasi standard gabungan

$S_{1} \quad=$ Simpangan baku eksperimen

$S_{2} \quad=$ Simpangan baku kontrol

$n_{1} \quad=$ Jumlah siswa kelompok eksperimen

$n_{2} \quad=$ Jumlah siswa kelompok kontrol

Kriteria pengujian adalah $\mathrm{H}_{1}$ diterima jika $Z_{\text {hitung }}>Z_{\text {tabel }}$ dimana $Z_{\text {tabel }}=\frac{1}{2}-\alpha($ uji satu arah $)$ dengan taraf signifikan $\alpha=$ $5 \%$.

\section{Hasil dan Pembahasan}

Berdasarkan uji validitas pre-test dan post-test yang dilakukan oleh 3 orang validator diperoleh bahwa baik pre-test maupun posttest keduanya valid dengan indeks 0,905 dan 0,875. Hal yang tidak jauh berbeda dengan uji validitas untuk lembar pengamatan aktivitas siswa yang memiliki indeks 0,845 . 
75 | al-Khwarizmi, Volume III, Edisi 2, Oktober 2015, Hal. 71 - 76

Berdasarkan uji normalitas dengan menggunakan rumus chikuadrat diperoleh bahwa $X_{\text {hitung }}^{2}=-149,1112<7,81=X_{\text {tabel }}^{2}$ dengan $\mathrm{dk}=4$ dan $\alpha=0,05$. Sehingga dapat dikatakan kelas kontrol dan kelas eksperimen sebelum perlakuan berasal dari populasi yang berdistribusi normal. Selanjutnya, berdasarkan uji homogenitas diperoleh bahwa $F_{\text {hitung }}<F_{\text {tabel }}$ atau 1,24 $<2$, 08 sehingga dapat dikatakan bahwa sampel yang diteliti berasal dari varian yang sama dalam hal ini homogen.

Berdasarkan hasil observasi pada kelas eksperimen mengenai kemampuan guru dalam mengolah pembelajaran dan hasil observasi aktivitas peserta didik dalam pembelajaran, pada pertemuan awal hingga akhir menunjukkan adanya peningkatan aktivitas. Pada pertemuan-pertemuan awal masih banyak terdapat hambatan dalam pengelolaan pembelajaran tersebut, namun seiring berjalannya waktu peningkatan aktivitas peserta didik selama proses pembelajaranterus mengalami peningkatan pada pertemuanpertemuan delanjutnya. Adanya kekurangan dan hambatan dalam setiap pembelajaran segera ditindak lanjuti sehingga tidak mengurangi efektivitas pembelajaran.

Pada pertemuan pertama, pembelajaran dengan menggunakan model pembelajaran group to group exchange (GGE) dalam pelaksanaannya terdapat berbagai hambatan. Salah satu hambatan yang paling mendasar yaitu peserta didik belum terbiasa dengan model pembelajaran group to group exchange (GGE) yang diberikan oleh guru. Hambatan lain yang ditimbulkan yaitu waktu sering banyak terbuang apabila peserta didik tidak dapat menjawab pertanyaan yang diberikan oleh guru. Kelebihan setelah diterapkannya model pembelajaran group to group exchange (GGE) yaitu mendorong peserta didik berpikir aktif, memberi kesempatan kepada peserta didik untuk menanyakan hal-hal yang kurang jelas sehingga guru dapat menjelaskan kembali, serta mengembangkan keberanian peserta didik dalam menjawab dan mengemukakan pendapat.

Uji hipotesis yang digunakan dalam penelitian ini adalah denagn uji dua rata-rata. Berdasarkan uji kesamaan dua rata-rata kondisi akhir antara kelas kontrol dan kelas eksperimen, diperoleh deviasi standar gabungan ( dsg ) $=8,48$ dan $Z_{\text {hitung }}=6,496$ dan $z_{\text {tabel }}=1,65$. Dimana taraf signifikan $\alpha=0,05$. Karena $Z_{\text {hitung }}>Z$ tabel maka $\mathrm{H}_{0}$ ditolak dan $\mathrm{H}_{1}$ diterima. Artinya, rata - rata nilai kelas eksperimen lebih baik dari kelas kontrol. Sehingga dapat disimpulkan bahwa penerapan model pembelajaran group to group 
Efektivitas Metode Pembelajaran ...| 76

exchange (GGE) efektif meningkatkan hasil belajar matematika siswa kelas VIII SMP Pesantren Modern Datok Sulaiman Putri Palopo.

\section{Kesimpulan}

Kesimpulan yang diperoleh dari penelitian ini adalah:

1. Secara deskriptif, rata-rata hasil belajar matematika siswa kelas VIII SMP Pesantren Modern Datok Sulaiman (PMDS) Putri Palopo yang diajar dengan metode pembelajaran Group to Group Exchange (GGE) lebih tinggi apabila dibandingkan dengan kelas yang tidak diajarkan dengan metode pembelajaran tersebut.

2. Metode pembelajaran Group to Group Exchange (GGE) efektif dalam meningkatkan hasil belajar matematika siswa kelas VIII SMP Pesantren Modern Datok Sulaiman Putri Palopo

\section{DAFTAR PUSTAKA}

Abdurrahman, Mulyono. Pendidikan Bagi Anak Berkesulitan Belajar, Jakarta: Rinekacipta, 2003.

Azwar, Saifuddin . Reliabilitas dan Validitas, Yokyakarta : Pustaka Pelajar, 2013.

B. Uno, Hamzah . Model Pembelajaran, Cet. I; Jakrta: Bumi Aksara, 2007.

Burhanuddin dan Esa Nur Wahyuni, Teori Belajar dan Pembelajaran, Cet. VII; Jogjakarta: Ar-Ruzz Media, 2012.

Nuharini, Dewi dan Tri Wahyuni, Matematika Konsep dan aplikasinya, Jakarta: Pusat Perbukuan Departemen Pendidikan Nasional, 2008

Ridwan, Dasar - Dasar Statistika, Cet.VIII; Bandung: CV.Alfabeta, 2010.

Sudjana, Nana . Penilaian Hasil Proses Belajar Mengajar, Cet.XI; Bandung: PT.Remaja Rodaskarya, 2006.

Slameto, Belajar dan Faktor-faktor yang Mempengaruhinya, Jakarta: PT. Rineka Cipta, 2003.

Syaodih Sukmadinata, Nana. Metodologi Penelitian Pendidikan, (Cet.V; Bandung: PT.Remaja Rosdakarya, 2009.

Subana, et.al., M. Statistik Pendidikan, Cet.II; Bandung: Pustaka Setia, 2005. 